\title{
World War Flu: War Rhetoric of The Australian Prime Minister on Coronavirus
}

\author{
IRYNA ALYEKSYEYEVA \\ Taras Shevchenko National University of Kyiv, Ukraine \\ irene.alexeyeva@gmail.com \\ OLENA KAPTIUROVA \\ Taras Shevchenko National University of Kyiv, Ukraine \\ VIRA ORLOVA \\ Taras Shevchenko National University of Kyiv, Ukraine
}

\begin{abstract}
During the coronavirus pandemic in spring 2020, political discourse was dominated by the language of war as the world's political leaders saturated their speech with the terminology of war. This article examines some properties of the speech delivered by Australian Prime Minister Scott Morrison in the parliament on March 22, 2020. The general framework of the study is Critical Discourse Analysis (CDA) which investigates how language is used in ideological and social contexts and how it relates to power. The material of the research requires to apply a more specialised tool, namely Political Discourse Analysis (PDA) that examines the relation between language and political agendas and ideology. The study considers the political and ideological contexts of the speech through the entire political process and decision making at the national level as well as the sociopolitical and cognitive aspects of the speech in the parliamentary setting. In particular, attention is paid to the war rhetoric that induces the public to conceptualise the virus as an enemy and thus to present the crisis as a threat to the nation. The article explores language means employed by the speaker to actualise rhetorical strategies aimed at justifying his government's measures taken to manage the crisis. To do this, the research looks into historical, cultural and psychological contexts of the speech as well as its political implicatures.
\end{abstract}

Keywords: political speech; war rhetoric; political discourse; critical discourse analysis; mental models

\section{INTRODUCTION}

The beginning of the year 2020 unexpectedly brought the major challenge to the world, the novel coronavirus disease. The virus has been declared a Public Health Emergency of International Concern (WHO, 30 January 2020), which caused the World Health Organization (WHO) to urge the countries to be "as aggressive as possible" in fighting COVID-19, the world's "public enemy number one" (Balibouse, Feb 11, 2020). As the WHO declared COVID19 a global pandemic on March 11, the language of war began worldwide to prevail over the language of normality in public discourse in general and political discourse in particular. Political leaders from different parts of the world addressed their audiences with speeches abundant in war rhetoric: warfare terminology, fighting imagery and divisiveness frames conceptualised the pandemic in the way that adhered to their nations' political and ideological context and prepared their people to face the threat. For example, Reuters Agency reported that the Chinese leader, Xi Jinping, visiting the city of Wuhan, where the virus had been said to originate, declared that China would win the "people's war" (Tian, Mar 13, 2020). Later on, French president Emmanuel Macron announced being "at war" with an "elusive enemy" (Macron, Mar 16, 2020), while his American counterpart Donald Trump labelled himself as "a wartime president" battling an "invisible enemy" (Trump, Mar 18, 2020). British Prime Minister Boris Johnson, in his turn, declared a "fight" in which "everyone is directly enlisted" (Johnson, Mar 23, 2020), and Australian Prime Minister Scott Morrison continued the theme, 
summoning the spirit of the ANZACs (the Australian and New Zealand First World War army corps) to fight against COVID-19 (Morrison, Mar 22, 2020).

Politics has been intertwined with power, since it constitutes the social order we live in: the power to make decisions, to control resources, to control people's behaviour and often to control their values and the way they view the world. In other words, politics determines how society is created and shaped. According to Fairclough, politics is mainly about making choices, about how to respond to situations and goals and how to choose policies (Fairclough \& Fairclough, 2012, p. 2). However, as modern societies are fragmented and each fragment may live by its own value system, making political decisions or choices is almost invariably a problematic process and the response to such choices is inherently uncertain.

To secure the dominance over people's mindset and to set the agenda for diverse society, political elites communicate to the public directly as well as engage the media (Teik \& Rahim, 2020). Whatever channel is chosen, any political action is always armed with language: language is used as a tool to construct reality and create dominant representations of this reality where objects gain their meanings and representations only through discourse ((Jorgensen \& Phillips, 2002, p. 20), see also (Buhrmann et al., 2007). Van Dijk (2000) sees language as "shield" exploited by those who are in power for "legitimisation of self", on the one hand, and, on the other hand, as a 'weapon' for 'delegitimisation' of the other power. This happens when a group or its members exert power over another group in order to control or limit their actions and affect their behaviour, knowledge, or ideologies (van Dijk, 1996, p.8485). In addition to its ability to represent reality, language has the ability to misrepresent it. If it is the case, language is used manipulatively to reproduce the power in all domains of discourse including the political one (Fairclough, 2006).

\section{PROBLEM STATEMENT AND RESEARCH OBJECTIVES}

The current health emergency provides linguists with a vast amount material to study language means and, through them, strategies employed by political leaders in order to cope with challenges and introduce unpopular policies.

The article explores the war rhetoric employed by Australian Prime Minister Scott Morrison in his speech on the epidemic delivered in the Australian Parliament on March 22, 2020. This particular address to the nation was intended to persuade Australians to forego any resistance to restrictions of their civil rights and freedoms that the government planned to impose in order to stop the virus from spreading. Thus, the speech is treated not as a mere text but rather as a political action carried out within a continuous political process and as a part in decision making at the national level.

The ambition of the analysis is to regard the political speech as a convergence of the speaker's mental representations, sociopolitical context and 'political implicatures', interpreted as a participant's "models of their own political identities, roles, goals, actions and beliefs" embedded in the context (Van Dijk, 2005, p. 69). Consequently, the research objectives are

- to explore the concepts and mental models through their verbalisation used to convince the audience of the emergency and

- to analyse the rhetorical strategies employed to justify controversial policies aimed at changing the social, economic and political systems. 


\section{LITERATURE REVIEW}

At times of crises, political leaders' reactions to a looming danger and their address to the nation influence the way that they are perceived by people. If politicians can successfully characterise a crisis as a national threat, they are likely to be seen as leaders of the national interest (Hart \& Tindall, 2009, p.346). Crises are remarkable because they are infused with a high level of uncertainty, which encourages politicians to use so-called militarised language. A number of scholars have noticed the current tendency to warfare rhetoric in nearly every domain of political and social life (see, for example, (Larson, 2005; Wiggins, 2012; Cespedes, 2014; Simons, 2015; Huckins, 2016)). Today, the "War on X" is a recurrent frame in public discourse (Flusberg et al., 2018, p. 2).

In the ongoing coronavirus pandemic crisis, the war-against-the-virus narrative has evolved into an acceptable part of the public discourse all over the world. Mass media and political leaders' speeches have been filled with the "World War Flu" language that contributes to the narrative and defines the situation at the national and international levels (Wooller, McDermott \& Sales, 2020). The extensive militarisation of the epidemic coverage has drawn the attention of a large number of scholars (see, for example, (Fotherb, 2020; Laucht \& Jackson, 2020; Enloe, 2020; Khan, 2020; Jenkins, 2020; Cassidy, 2020; Serhan, 2020; Cox, 2020; Lethbridge, 2020; Semino, 2020) to name just a few).

The war discourse is always used as a specific action-oriented language either to encourage the public to face a certain threat or to avoid the responsibility for causing these threats. Enloe (2020) argues that war waging is such an appealing analogy precisely because so many political leaders pick their wars cautiously and choose carefully what they want people to remember about each conflict. Militarised language is the most powerful and appealing communicative channel to the collective mind of a nation. Rhetoric plays an influential part in managing crises, therefore political leaders frame the disease outbreak in war imagery and 'fear-language' to get the public involved in what they call 'national interest' and make the audience accept the leaders' decisions, which enhances their authority. Henceforth, "waging a war" is the most deceptively alluring strategy to mobilise private and public resources in the face of danger (Enloe, 2020) as well as to justify governments' unpopular policies and to shield the governments from responsibility (Larson \& Wallis, 2005, as cited in Fotherby, 2020).

The research into governmental decisions on curbing the coronavirus in Malaysia and Singapore explores public discourse of these countries and uncovers that COVID-19 is presented as an 'enemy'. The disease is termed 'musuh senyap' (silent enemy) by Malaysian Prime Minister, Mr. Muhyiddin, (May 10, 2020) and 'common enemy' by Singaporean Prime Minister, Mr. Lee (April 14, 2020), both metaphors implying danger and developing "a combative frame" (Rajandran, 2020, p. 265). Interestingly, the Prime Ministers' speeches do not elaborate the characteristics of the virus, although the virus' specifics were emerging after continuous study. Yet, the Prime Ministers keep scientific details to the minimum and employ metaphors to maintain the imprecise nature of COVID-19 (Rajandran, 2020, p.264). (It should be mentioned that similar vagueness of political discourse is described in (Khalil, 2020), though the topic of the discourse is different.)

It is remarkable that COVID-19 is verbalised through war metaphors all over the world: they are registered in public discourse in Italy (Tan et al., 2020), Southeast Asia (Rajandran, 2020), and the United States (Olimat, 2020) (also see (Connolly, 2020)). War rhetoric on the coronavirus pandemic is so globally pervasive that some scholars have urged speakers to stop using it, since metaphorical expressions may lead to distorted mental representations (see, for example, (Arawi et al., 2020; Boyte \& Throntveit, 2020; Burke, 2020)).

The explanation of this militarised representation of the pandemic lies in that the warfare imagery enables politicians to simplify COVID-19 and to categorise as its allies 
anyone who resists the restricting measures imposed by the governments. War metaphors impact on the representation of reality promoted in the society but simultaneously help to conceal speakers' ideological orientation.

\section{THEORETICAL FRAMEWORK}

Analysis of political discourse has been extensively studied by numerous scholars employing the apparatus of Critical Discourse Analysis (CDA) (see, for example, (van Dijk, 1993, 1997, 2001; Fairclough 2000, 2002; Mulderrig, 2003; Wodak \& Chilton, 2005; Jones \& Collins, 2006; Weiss \& Wodak, 2007; Wodak \& Meyer, 2009)). Van Dijk considers CDA to be "a type of analytical research that primarily studies the way social power, abuse, dominance, and inequality are enacted, reproduced, and resisted by text and talk in the social and political context" (Van Dijk, 2001, p.353). Since the main concern of CDA is not the use of language as such but rather its use in ideological and social context and its relation to power, Critical Discourse Analysis "requires true multidisciplinarity, and an account of intricate relationships between text, talk, social cognition, power, society and culture" (van Dijk, 1993, p.253).

CDA has evolved into Political Discourse Analysis (PDA) and it is PDA that the current research is based on. The key objective of PDA is to examine the ways in which a politician's language choice depends on intended political effects. Chilton and Schaffner (1997) see the task of Political Discourse Analysis in relating the linguistic behaviour to politics or political behaviour. In other words, PDA deals with political dialogic processes between political actors, such as presidents, prime ministers, members of government, parliament, or political parties (van Dijk, 1997). Consequently, PDA is not only about political discourse; it is a 'critical enterprise' which is concerned with basic notions in power relations, namely production of political power, domination and power abuse (Van Dijk,1998).

PDA integrates different aspects of the context such as setting and participants; then it investigates the speech and its textual properties: namely its topic, semantic function, style and rhetoric (van Dijk, 1993, p.270). The less powerful participants, i.e., recipients, might be controlled and their "freedom of choice may be restricted by dominant participants" (ibid., p.256, 260). Dominant speakers are "able to indirectly manage the public mind" by making use of those "structures and strategies that manipulate the mental models of the audience in such a way that preferred social cognitions tend to be developed, that is, social cognitions (attitudes, ideologies, norms and values) that are ultimately in the interest of the dominant group" (ibid., p.280-281). Thus, political discourse, according to van Dijk (2002), is highly potent: it permeates all major issues in the public sphere, shapes people's understanding of social and political realities, and may affect the quality of public life. Therefore, political discourse can only be fully comprehended when there is an explicit understanding of the social context where it is produced (van Dijk, 2002, p.225, 234). In other words, it is important to recognise that political discourse and its effect are heavily influenced by who the discourse participants are, when the discourse is produced and for what purpose the communicative process takes place.

Political speeches as a genre of political discourse aim at informing the audience, i.e., at highlighting a political problem. In addition, they serve as a communicative channel to convey the speaker's beliefs, ideas and the speaker's cognitive representation of these beliefs within a certain political, social and ideological context. By using rhetorical devices to excite audiences, by persuading them and claiming leadership, a political speech becomes an essential means of influencing people's knowledge and behaviour (Carreon \& Svetanant, 2017). In other words, language employed in political speeches helps political actors to create a reality and facilitates the audience's acceptance of this reality. 


\section{METHODOLOGY AND DATA SELECTION}

The methodology for the research has been put forward by Teun van Dijk (1993, 2001, 2005) who sees Critical Discourse Analysis as a multidisciplinary approach that "tries to 'triangulate' social issues in terms of a combined study of discursive, cognitive and social dimensions of a problem" (van Dijk, 2005, p. 65). This assumption is particularly true for political discourse, whose analysis should not be restricted to thematic features of text and talk, but should also include a systematic reasoning of their contexts in the political process (ibid., p. 66). Thus, the research methodology employs content analysis aimed at calculating the frequency of lexemes, which enables to identify the key themes of the speech. The second stage of the research relies on qualitative analysis and follows the conventional procedure of Political Discourse Analysis (see, for example, (van Dijk, 1993, 1997, 1998; Chilton, 2004; Chilton \& Schaffner, 2002)); the relation between language and political agendas and ideology is viewed from the perspective, suggested in (van Dijk, 1998, 2002, 2006; Wodak, 1989; Wodak \& de Cilia, 2006).

The data for the research is provided by the fourteen-minute-long speech delivered by Australia's Prime Minister Scott Morrison on March 22, 2020, in the Parliament (Morrison, 2020). The address to the MPs and the entire nation consists of 1689 words that herald stringent social and economic restrictions of the lockdown and justifies the drastic changes of the social order.

\section{FINDINGS}

\section{QUANTITATIVE ANALYSIS OF VOCABULARY}

Content analysis of the Prime Minister's speech reveals combat and warfare vocabulary (to battle, to defend, frontline, to overcome, to overtake, to protect, sacrifices, shield, to win, war), modal verbs of obligation and capacity must and can as well as words to denote a crisis situation and/or danger (challenge, test, burden). The word (corona) virus is used 8 times. These lexical and grammatical items draw the 'dark side' of the situation.

There is, however, a 'brighter' side: the crisis is manageable if there is solidarity within the nation, all citizens and all political actors included. The image of the consolidated community led by the strong leader is created by numerous second-person pronouns we, our, $u s$, the substantivised adjective Australians, the adverb together and the first-person pronoun $I$ that refers to the Prime Minister himself. The results of the quantitative analysis are given in Table 1 below:

TABLE 1. Number of occurrences of consolidating and war-related vocabulary

\begin{tabular}{cccc}
\hline $\begin{array}{l}\text { Verbalisation of unity and solidarity } \\
\text { lexemes }\end{array}$ & \multicolumn{2}{c}{$\begin{array}{c}\text { Verbalisation of adversity and war } \\
\text { lexemes }\end{array}$} & $\begin{array}{l}\text { frequency of occurrence } \\
\text { frequency of occurrence }\end{array}$ \\
\hline we & 57 & & \\
our & 27 & & \\
can & 14 & & \\
$I$ & 12 & & 9 \\
Australians & 12 & must & 8 \\
us & 11 & coronavirus & 7 \\
challenges & 5 \\
together & & save lives & 5 \\
to support & 8 & test & 3 \\
Australia & 5 & war & 3 \\
& & crisis & 2 \\
to help & 3 & to protect & 42 \\
& & &
\end{tabular}


A comprehensive analysis of the speech that uncovers the speaker's deeper messages and longterm strategies requires research into its structure, semantics (including implicatures) and extralingual context. Since semantics and context are tightly intertwined, we will consider them together.

\section{STRUCTURE}

Short though the speech may be, it consists of five parts:

- the first part is meant to describe the emergency situation:

(1) We gather today at the time of great challenge for our nation and indeed the world.

- the second part brings back the glorious history of Australia and its people who succeeded in overcoming adversities:

(2) So we summon the spirit of ANZACs of our Great Depression generation, of those who built The Snowy, of those who won the great peace of the second world war and defended Australia. That is our legacy that we draw on at this time.

- the third part depicts the Australians as consolidated nation at all levels:

(3) I want to thank in particular the nation's premiers and chief minsters for coming together to form Australia's first ever national cabinet, a cabinet of all Australians governments, five labour leaders, four coalition leaders.

- the fourth part presents the lockdown restrictions and the government' compensatory measures:

(4) Last night all the states and territories through the national cabinet agreed to an even more stringency... Yesterday, the Treasure and I announced an economic support package, a safety net package, unprecedent in our nation's history in its scale and coverage.

- the final passage combines a picture of better "post-pandemic" Australia and an urge for solidarity:

(5) When the virus passes and it will, we will be stronger on the other side. This will be a test of all Australians. It is a test of our nation, of our spirit.

Thus, the speech structure is a frame: it starts with the statement of a challenge and it ends with mentioning the challenge, yet in the beginning of the speech the audience find themselves setting out on a journey (challenge in (1) and test in (2)), whereas the conclusion asserts the journey is manageable (we will be stronger on the other side).

\section{SEMANTICS AND CONTEXT}

The Prime Minister begins his speech with explicitly defining the current situation as a crisis comparable to war:

(6) ... this will put us all to the test at no time like this since the World War II. But together, Australia, we are up to this challenge.

The pathos equals speeches of WWII: this conceptualisation of the coronavirus reinforced with the reference to the world war presents the virus as an enemy that has invaded the country. Remarkably, this mental model is maintained throughout the speech: the whole world is waging a war against this intruder and the Australian government as a part of the international community takes legitimate actions locally, following the legal global context, to save the country's people. Thus, the local political act is presented as implementation of the overall perception of the current global political situation (van Dijk, 2005, p. 67).

By comparing the current situation in the world to WWII, the Prime Minister states the globality of the coronavirus threat and argues that his government's actions go along with the 
rest of the world. In other words, the Australian Prime Minster draws on the general semantic and rhetorical strategy typical of war discourse which is ingroup/outgroup polarisation built on We (the whole world) vs. the Enemy (the virus) dichotomy. Consequently, his government becomes a part of the internationally united community (a part of the ingroup).

In his speech, Morrison appeals to shared national identity, national spirit and solidarity by repeating Australia, Australians, together, each other, we, our nation:

(7) The coronavirus that is sweeping the world will continue to change the way we live but we must not allow it to change who we are as Australians.

(8) So together, and with the rest of this world we face this unprecedented challenge.

(9) We must resolve today as Australians to come together and to pledge to each other across our nation that this coronavirus will not break our Australian spirit.

The Prime Minister lays the foundation of the semantic context of the speech by giving four examples that illustrate Australians' ability to overcome ordeals with exceptional courage and endurance: Australian soldiers in WWI, the generation that lived during the Great Depression, the generation that built the Snowy Mountain project, and Australian soldiers in WWII. These examples form the basis of the semantic context of the speech:

(10) So, we summon the spirit of Anzacs, of our Great Depression generation, of those who built The Snowy, of those who won the great peace of the Second World War and defended Australia.

The Prime Minister's speech is filled with implicatures. In (11), the politician does not only confirm the unprecedented threat from the enemy that is stronger than all the policy makers and regulators in the country at all levels and stronger than any political action they will take, but he also implies legitimation of the unwelcome regulations, mostly restrictions, the government will impose:

(11) Meeting this challenge is bigger than any Australian, it's obviously bigger than politics, it's bigger than any of us who are in this chamber: prime minister, leader of the opposition, ministers, shadow ministers, members of parliament, bigger than all of us. It's bigger than premiers, chief ministers, captains of industry, leaders of union movement, it's bigger than all of us.

Another implication in (11) is hedging the Prime Minister's responsibility for coping with the crisis and generously sharing it with political actors at all levels as well as preparing people for the future defeats because the enemy is bigger not only than any Australian but all the Australians regardless of their power position.

To claim the unity of all political actors including the opposition, Scott Morrison lists all powerful subjects that support the government's initiatives. Thereby he legitimises all the decisions and delegitimises any objections to what the cabinet of all Australians decides. The Prime Minister's intention behind this statement is to declare insubstantial, even harmful any legitimate legal and/or constitutionally justified opposition:

(12) I want to thank in particular the nation's premiers and chief minsters for coming together to form Australia's first ever national cabinet, a cabinet of all Australian governments ...I want to thank the leader of opposition for the cooperation he and his colleagues have afforded us here ... as we battle this dual health and economic crisis.

Once the government did what it should, the duty of the public is to cooperate, follow and respect the Cabinet's decisions. The idea of obligations is expressed with the extensive use of modality markers: the modal verb must, the noun duty, responsibility, adjectives important, vital: 
(13) ... we must not let that fear overtake us. We must focus instead on what we do know, what we can control.

(14) To the responsibility we know, we must take our own actions and our own behaviours.

(15) It is important that we do all we can to ensure in the difficult months ahead that no Australian goes through this alone

(16) These changes are vital to slow the spread of this virus to save lives. It will be absolutely vital that every Australian respects and follows the healthy social distancing measures, that all the Australian governments have implanted in order to flatten this curve and to save lives.

Scott Morrison effectively constructs fear and elevates anxiety among the public by predicting the unimaginable (we will face more issues that none of us now can imagine) and openly admitting that little is known about the coronavirus, which arouses fear:

(17) It is the understandable fear of the unknown and there is much that is not known about the coronavirus.

The lack of information of the enemy makes a victory uncertain. Moreover, even if the battle is won, it may take months of fighting and adversity. This idea keeps resurfacing throughout the speech:

(18) In months ahead we will face more issues that none of us now can imagine.

(19) Australians will be living with this virus... for at least the next 6 months, it could be longer.

(20) There is no short-term solution to this.

(21) The test's hardships and sacrifices that will be placed on all of us, on our national character will undoubtedly break our hearts in many occasions in the months ahead.

Framing the mental model of the unknown frightening enemy by utilising the warfare rhetoric implicates that the government is changing its behaviour to face this enemy's danger. The state's change of policies entails an individual and collective behavioural change at social, political and economic levels as well as a change of the nation's lifestyle and worldview. A fearful community challenged by an outside danger is less resistant to changes, which turns exploiting the public fear into the shortest and most effective way of implementing unpopular agendas. Imposing restrictions starts with the political discourse supported by media, politicians, decision makers, scientists, and opinion leaders: their messages, laced with the war language, plant and then keep alive fear and anxiety. (22)-(21) are examples of the Prime Minister's persistent 'drill': the danger is dire, therefore, everyone will have to comply with the new lifestyle:

(22) Life is changing in Australia for every Australian, and life is going to continue to change for many young and old. 2020 will be the toughest year of our lives.

(23) Last night all the states and territories through the national cabinet agreed to an even more stringency of social distancing rules that will change further how we all live our lives.

(24) These changes are vital to slow the spread of this virus to save lives.

As soon as a usual reaction to fear is seeking protection, ordinary citizens, i.e., the majority, will choose to become dependent on their defenders and, consequently, will accept their policies to cope with the crisis. In the coronavirus case, just like in any 'threat-fromoutside' situation, the role of defenders is played by governments and other political actors in leading positions. It is these people who take on the responsibility and are capable of leading the nation through the ordeal. Scott Morrison claims the defender's role for his government. He expresses his determination and inner strength in the following sentences with the first- 
person pronoun I combined with the words that contain the seme 'conviction' (to assure, certainly) and ability (can):

(25) I'll say this: while you may not be able to go to church, the synagogue, the temple, or the mosque, I certainly call on all people of faith in our nation to pray. And I can assure you... I give them that assurance. That I give them that encouragement, as I have to stand that stuff down, that I commit to do all I can on the other side to stand them back up again.

Yet, the Prime Minister also uses we to show that he is the leader of the team that embraces the entire, united political elite:

(26) We will do all what we can in this place, as a parliament, as a government to help see you through. Today we assign that we both can do this and we will do this. And we will do this together.

\section{DISCUSSION}

Politicians in general and governments in particular are expected to take an action during crisis situations, but before doing this, they have to bring their people together to a common view and to present themselves as reliable managers capable of coping with the challenge (Boin, 2009, p.309).

On March 22, 2020, the Australian Prime Minister takes advantage of the physical and political context when he presents the course of actions designed to handle the challenge of the coronavirus. Thus, the setting of the speech (the Parliament) is an influential pragmatic token which implicates that all Australians are participants in this fight, since the Parliament is the representative of the entire nation. By assuring that this cabinet, where all representatives of the Australian nation gathered to come together with the government, where even the opposition cooperates to form the first ever national cabinet, the Prime Minister emphasises that he calls for national consensus, which is a popular political move to meet threats from outside (van Dijk, 2005, p. 88), such as wars.

In times of crises, war rhetoric appears the most persuasive and appealing tool to influence the collective mind of the public, since militarisation of crisis discourse helps to restrict the recipients' conceptualisation of the situation to a war frame as well as undermine or marginalise other conceptual representations of this crisis. The remarkable density of the war-framed context in Prime Minister Morrison's political discourse indicates his attempt to deconstruct (or at least shift) the public's mental model from the social representation of the familiar status quo, i.e., normalcy they used to live with, to a mental model that incites the need to accept the forthcoming unfamiliar situation as necessarily unavoidable. As a result, the warfarelike context of the Prime Minister's speech marginalises the government's opponents and simultaneously generates a new mental model that is essentially grounded inAustralians' duty, i.e., dictating what people from the ingroup must do: the ingroup must not criticise the government's policies and must comply with them because the changes the government will instigate are vital to save lives.

Scott Morrison uses the war rhetoric to carry out the strategy of emotional appeal by arousing two oppositely directed feelings: fear and pride. The pervasiveness of the fight and defensive tone in the discourse mediated to the public is saturated with the realisation of danger and this makes it a compelling communicative channel for people who are emotionally driven to conceptualise the virus as an evasive, pervasive and dangerous enemy. Mediating political discourse to the public leads to making it a discursive part of everyday communication, which has a cognitive and behavioural effect on the public's conceptualisation of the danger. Hence, inducing terrifying image of the enemy helps to raise public awareness and motivates 
unconcerned members of the society to take the threat seriously. This helps to reach the widercommunity and urge it to rally in the face of the menace.

Yet, Scott Morrison emphasises the consolidation of the nation in this time of trial and recalls the historical events that prove Australians' strength and endurance both in wartime (the world wars of the $20^{\text {th }}$ century) and in the economic predicament (the Great Depression). This imagery is ideologically marked, it appeals to national identity and rouses the audience's pride and determination by implying that Australians today will be again the noble heroes who will fight against the virus, patiently curbing the economic crisis caused by this enemy, and will rebuild their country again, just like the Australians involved in the Snowy Mountains scheme (1949-1974).

The phrase to save lives repeated five times in the speech intends to implicate that the new governmental policies are to be taken as legitimate and there is no other choice but to do their duty, to defend the nation. Consequently, the policies are an "honorable" action made out of "necessity" and the authorities do not act "against national interest". Necessity is a "very effective semantic strategy of argumentation" which is part of political implicatures in the rhetoric of war (van Dijk, 2005, p. 88). It means there is no other way out. Framing actions in this way, one succeeds in eliminating the notion of choice, on the one hand, and, on the other hand, one seems very responsible. In other words, to be a crisis manager is stressful and difficult because one has to introduce unpopular measures. Moreover, by putting a situation in such a frame, one manages to present one's actions as "necessary, logical, comprehensible, unavoidable or otherwise acceptable" (ibid., 2005, p.71).

By constructing this new reality, the speaker is implanting a new cognitive mental model into the public's collective psyche: the audience is both psychologically and emotionally forced to change their social representations at almost all levels. As a result, driven by the new social representation of the enemy threatening their existence, the audience is likely to accept the changes made by the government in all spheres. If planned and performed well, the strategy brings the intended effect: the level of fear becomes disproportionately higher than the awareness of the threat, which mutes any criticisms of new policies, gains people's compliance and makes the control over a panic-stricken community easier. Since the changes are emphasised to be vital for saving the lives of Australians, the Prime Minister shares the responsibility with the public. In other words, adopting the changes is a test for all Australians and for the spirit of the nation, the more people do the right thing (i.e., the more they stick to the new rules), the more lives will be saved.

\section{CONCLUSION}

The war frame has always been present in the political and public discourse when it comes to pandemics or diseases. However, the density of warfare terms and the war-frame strategy used in Australian Prime Minister's speech, delivered on March 22, 2020, is noticeably greater than may be expected in a health emergency. Thus, the content analysis of the speech has revealed, on the one hand, militarisation of health issues during the coronavirus period as the most pervasive strategy to address the public and, on the other hand, the Prime Minister's appeal to unite in the face of danger.

The language means and rhetorical strategies are chosen by the Prime Minister in order to influence audiences most effectively, the ultimate aim being to legitimise new policies and regulations that will change the Australian customary lifestyle and worldview. In the attempt to make the nation accept the government's unpopular regulations, Scott Morrison tries to make the audience involved emotionally by appealing to people's need for security and by drawing on shared history and cultural values. To achieve this, he employs war-related vocabulary as 
well as grammatical means (pronouns, modal verbs). The Prime Minister's rhetoric aims at introducing a new social representation: the Australians are threatened by the virus and, to save lives, they must steel themselves for a fight under the leadership of the government.

The rhetorical strategies employed by the speaker are appeal to emotions, positiveingroup/negative-outgroup dichotomy and legitimation/delegitimisation that are actualised by metaphorical references to the virus metaphorically as well as emphasising the international community's consensus, national consolidation, national interest and necessity. The political implicatures embedded in the speech context serve as models that the Australian Prime Minister uses to construct a representation of the new reality and to facilitate its acceptance.

\section{REFERENCES}

Arawi, T., Cutter, A. M., Chakraborty, R., \& Astous, M. (2020). A Call to Cease the Use of War Metaphors in the COVID-19 Pandemic. Retrieved from https:/www.researchgate.net/publication/34223279

Balibouse, D. (2020, February 11). World must consider coronavirus 'public enemy number one': WHO. Reuters. Retrieved from https:/www.reuters.com/article/us-china-health-who-containment/world-mustconsider-coronavirus-public-enemy-number-one-who-idUSKBN20521X

Boin, A. (2009). Crisis leadership in terra incognita: why meaning making is not enough. In P.Hart \& K.Tindall (Eds.) Framing the global economic downturn: crisis rhetoric and the politics of recession (pp.309-314). Canberra: ANU E Press

Boyte, H. C., \& Throntveit, T. (2020). War is a Poor Metaphor for This Pandemic. Retrieved from https://www.academia.edu/43156429/War_Is_a Poor_Metaphor_for_This_Pandemic

Burke, L. (2020). Covid-19: of Gods, Demons, Armies and Profanities: The Language and Metaphors which Shape a Global Pandemic in the $21^{\text {st }}$ Century. DOI: 10.13140/RG.2.2.19238.96323

Carreon, J.R. \& Svetanant, C. (2017). What Lies Underneath a Political Speech? Critical Discourse Analysis of Thai PM's Political Speeches Aired on the TV Programme Returning Happiness to the People. Open Linguistics, 3(1), 638-655

Chilton, P. \& Schäffner, C. (2002). Introduction: themes and principles in the analysis of political discourse. In P.Chilton \& C.Schäffner (Eds.) Politics as text and talk (pp.1-41). Amsterdam: John Benjamins.

Connolly, C. (2020). War and the Coronavirus Pandemic. Third World Approaches to International Law: Reflections, 15, 1-7. Retrieved from: https://www.researchgate.net/publication/340536651_War_and_the_Coronavirus_Pandemic

Enloe, C. (2020). COVID-19: “Waging War” Against a Virus is NOT What We Need to Be Doing. Retrieved from: https://www.wilpf.org/covid-19-waging-war-against-a-virus-is-not-what-we-need-to-be-doing/

Fairclough N. (2006). Genres in political discourse. In K. Brown (Ed.) Encyclopedia of language and linguistics (vol. 5, pp.32-38). Boston: Elsevier

Fairclough, I. \& Fairclough, N. (2012). Political Discourse Analysis: A Methods for Advanced Students. London: Routledge

Flusberg, S. J., Matlock, T., \& Thibodeau, P. H. (2018). War metaphors in public discourse. Metaphor and Symbol, 33(1), 1-18. Retrieved from https://www.tandfonline.com/doi/full/10.1080/10926488.2018.1407992

Fothebry, J. (2020). The 'Invisible Enemy': A Critical Look at the Use of Military Metaphors and Anthropomorphisation During The COVID-19 Pandemic. Retrieved from: https://medanthucl.com/2020/05/13/the-invisible-enemy-a-critical-look-at-the-use-of-militarymetaphors-and-anthropomorphisation-during-the-covid-19-pandemic/

Hart, P. \& Tindall, K. (2009). Public leadership and the social construction of economic catastrophe. In P.Hart \& K.Tindall (Eds.) Framing the global economic downturn: crisis rhetoric and the politics of recession (pp.331-348). Canberra: ANU E Press

Johnson, B. (2020, March 23). PM address to the nation on coronavirus. GOV. UK. Retrieved from: https://www.gov.uk/government/speeches/pm-address-to-the-nation-on-coronavirus-23-march2020?utm_source=3e82ab56-0ac0-456b-9c3c-

7e48ba3325f0\&utm_medium=email\&utm_campaign=govuk-notifications\&utm_content=immediate

Jorgensen, M. \& Phillips, L. (2002). Discourse analysis as theory and method. London: Sage Publications

Larson, B. M. H., Nerlich, B., \& Wallis, P. (2005). Metaphors and Biorisks: The War on Infectious Diseases and Invasive Species. Science Communication, 26(3), 243-268

Macron, E. (2020, March 16). We are at war. $B B C$. Retrieved from https:/www.bbc.com/news/av/51917380/coronavirus-we-are-at-war-macron 
Morrison, S. (2020, March 22). Coronavirus: PM summons spirit of the Anzacs to fight against COVID-19|Nine News Australia. Retrieved from https:/www.youtube.com/watch? $\mathrm{v}=$ HiolbLib35E

Olimat, S. N. (2020). Words as Powerful Weapons: Dysphemism in Trump's Covid-19 Speeches. 3L: The Southeast Asian Journal of English Language Studies, 26(3), 17-29. http://doi.org/10.17576/3L-20202603-02

Rajandran, K. (2020). A Long Battle Ahead': Malaysian and Singaporean Prime Ministers Employ War Metaphors for COVID-19. Journal of Language Studies, 20 (3), 261-267. http://doi.org/10.17576/gema2020-2003-15

Tan K. H., Peter W., Hazita A., Imran H. A., Ruzy S. H., Hajar A. R., Mohd M. I., Nur E. M. S., Robert L., \& Iztok K. (2020). Covid-19 Insights and Linguistic Methods. 3L: The Southeast Asian Journal of English Language Studies, 26(2), 1-23. http://doi.org/10.17576/3L-20202602-01

Teik, O. C., \& Rahim, H. A. (2020). The Discourse of Nation-Building in the Goods and Services Tax (GST) Malaysia Info Web Portal News Articles. 3L: The Southeast Asian Journal of English Language Studies, 26(1), 119-134. http://doi.org/10.17576/3L-2020-2601-09

Tian, Y. L. (2020, March 13). In 'People's War' on coronavirus, Chinese propaganda faces pushback. Reuters. Retrieved from https://www.reuters.com/article/us-health-coronavirus-china-propaganda-a/in-peopleswar-on-coronavirus-chinese-propaganda-faces-pushback-idUSKBN2100NA

Trump, D. (2020, March 18). Coronavirus task force holds briefing as Trump seeks additional funding. Retrieved from https:/www.youtube.com/watch?v=GZRpSQYh5yg

Van Dijk, T. A. (2005). War rhetoric of a little ally: Political implicatures of Aznar's legitimization of the war in Iraq. Journal of Language and Politics 4(1), 65-92

Van Dijk, T. A. (1993). Principles of Critical Discourse Analysis. Discourse \& Society 4(2), 249-83

Van Dijk, T. A. (1996). Discourse, power and access. In C. R. Caldas-Coulthard \& M. Coulthard (Eds.). Texts and Practices. Readings in Critical Discourse Analysis (pp.84-104). London: Routledge

Van Dijk, T. A. (1997). Political discourse and racism: Describing others in western parliaments. In S.Riggins (Ed.) The Language and Politics of Exclusion: Others in Discourse (pp.31-64). Thousand Oaks, CA: Sage

Van Dijk, T. A. (1998). What is political discourse analysis? In J.Blommaert \& C.Bulcaen (Eds) Political Linguistics (pp.11-52). Amsterdam: Benjamins

Van Dijk, T. A. (2000). Parliamentary debates. In R. Wodak \& T. A. van Dijk (Eds.) Racism at the Top. Parliamentary Discourses on Ethnic Issues in Six European States (pp.45-78). Klagenfurt, Austria: Drava Verlag

Van Dijk, T. A. (2001). Critical discourse analysis. In D. Tannen, D. Schiffrin, \& H. Hamilton (Eds.) Handbook of discourse analysis (pp. 352-371). Oxford: Blackwell

Van Dijk, T. A. (2002). Political discourse and political cognition. In P.Chilton \& C.Schäffner (Eds.) Politics as Text and Talk: Analytic Approaches to Political Discourse (pp.203-234). Amsterdam and Philadelphia: John Benjamins

Wooller, S., McDermott, N., \& Sales, D. (2020, January 23). WORLD WAR FLU. The Sun. Retrieved from https://www.thesun.co.uk/news/10799738/coronavirus-could-already-spread-uk/

World Health Organization (2020). WHO Timeline - COVID - 19. Retrieved from https://www.who.int/newsroom/detail/27-04-2020-who-timeline---covid-19 